\title{
Beyond the written word: Newspapers as critical literacy teaching tools in the South African classroom
}

\author{
Rockie Sibanda
}

University of Johannesburg, Department of Languages, Cultural Studies and Applied Linguistics

rsibanda@uj.ac.za

\section{ARTICLE INFO}

Article history

Received 22 September 2021

Revised 10 December 2021

Accepted 30 December 2021

\section{Keywords}

Critical literacy

Inclusive critical curriculum

Newspapers

Social justice

South African township

\section{ABSTRACT}

This paper provides the rationale and purpose for a critical literacy awareness strategy, implemented to 20 English second language students at a township secondary school in South Africa. This empirical study provides insight into using newspapers as a pedagogical tool to develop students' language and critical literacy skills. Using different classroom activities and class discussions, the teacher helped the students to read beyond different texts and raised their awareness of different ideologies that inform texts. Working in pairs and groups, the learners engaged with different genres of texts. In this study, special emphasis is promoting critical thinking for social justice where critical literacy is used as a tool to better understand and improve the world. Findings of the study show students engaging in critical conversations without being directed into one way of thinking, which leads to significant improvement in their critical thinking. This further shows that texts that raise questions about different discourses can create an inclusive critical curriculum. It can be concluded that students can learn best when presented with a context they can identify with and are able to tap to their everyday experiences.

This is an open access article under the CC-BY-SA license.

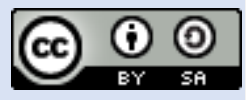

How to Cite: Sibanda, R. (2021). Beyond the written word: Newspapers as critical literacy teaching tools in the South African classroom. English Language Teaching Educational Journal, 4(3), 174-186.

\section{Introduction}

All over the world, newspapers provide people with valuable information. They can influence people's way of thinking and modify their views. However, Abbas and Talaat $(2019$, p. 400) argue that "news printed is not a reality; it is a reality constructed and recapitulated". Newspapers are an ideological phenomenon underpinning reality and employ discursive means of power to do it (Kress, 1985). As Kress (1985) observes, in newspapers language is assigned certain linguistic terms, like lexes, phrases and sentences, by the one who uses it. The form it appears in newspapers is always assigned in a convincing way (Kress, 1985). Researchers have highlighted newspapers' ability to shape peoples' perceptions, manipulate and change beliefs (Pratiwi, Nofrahadi, Pendri, Komalasari \& Sumarlam. 2020).

With prevalence of fake news all over the world, it is essential for teachers to equip students with critical tools and thinking skills to ask potent questions about texts' accuracy, authority, attribution and purpose (The General Teaching Council for Scotland, 2018). The term "fake news" is not new (Tandoc, Lim \& Ling, 2017). Modern discourse, particularly media reporting, define fake news as viral posts based on fabricated accounts made to sound like genuine news reports (Tandoc, et. al., 2017). According to Allcott and Gentzkow (2017), fake news can be defined as "news articles that are intentionally and verifiably false, and could mislead readers" (p. 213). A case in question is the current reporting on COVID-19, as the world is still in grips of the pandemic. There is a lot of fake news in 
circulation regarding how the virus is spread, particularly in Africa (Ahinkorah, Ameyaw, Hagan, Seidu \& Schack, 2020). Although media plays an important role to connect governments, health workers, and the public by reporting the news and information (Mintarsih, Kodrat, \& Emiliasari, 2020), rigorous education campaigns are required to dispel myths surrounding COVID-19. Students in particular need to be equipped with analytical and critical thinking skills to enable them to make informed decisions on what is credible news.

A survey conducted on 12 to 15 year old children in UK found that 20 per cent of [them] placed complete trust in the accuracy of the news sources reported online (Ofcom 2016). In addition, Picton and Teravainen (2017) found that children in England lack "critical literacy skills to enable them to analyse, problematise or 'read between the lines' of on-line and off-line texts". As Luke (2014) advises, critical literacy should encourage critical engagement with texts, discourses and modes of information, which Stone (2017) describes as 'vital aspect of the literacy skillset'. Consequently, critical literacy should go beyond mere thinking. Entrenched in "critical social theories" of Paulo Freire (1972), critical literacy should teach students to question and challenge general assumptions made in texts by analysing language and power. Shor, Matusov, Marjanovic-Shane and Cresswell (2017) advocate critical pedagogy that goes beneath surface meaning as students reflect instead of expecting the educator to explain for them what things mean and what to believe. Critical literacy should help students develop to active, knowledgeable citizens who are able to "read both the word and the world critically" (Freire, 1972). In the classroom, we should promote a critical literacy approach in which students strive to analyse texts for bias. It is vital for students to be able to identify bias because it is a key aspect of being critically literate, which is more than merely identifying stereotype (GTC, n.d). Being able to analyse facts to form a judgment is the core of critical thinking when students develop the ability to critique the logic of texts. This study draws on some interesting activities for promoting critical thinking in the language classroom suggested by Hughes (2014), including: 1) developing a critical mind set; 2) evaluating the reliability of sources; 3 ) stance; 4) fact or opinion; 5) reading between the lines; 6) writing headlines and 7) predicting the content of the text.

There is an assumption that texts, as constructions, contain points of view of the writer or producer, which should be understood by the reader. As Gainer (2012) advises, individual readers should unpack the socially constructed nature of literacy, to assist them uncover the profound meaning of texts. As a tool to achieve social justice, it is hoped that by applying the frameworks of inquiry, reflection and action, marginalised students can be transformed to critical thinkers who can voice their struggles (Luke, 2012). Equally and lightly, as Lankshear and McLaren (1993, p. xviii) put it:

In addressing critical literacy, we are concerned with the extent to which, the ways in which, actual and possible social practices and conceptions of reading and writing enable human subjects to understand and engage the politics of daily life in the quest for more truly democratic social order.

This study embraces Lankshear and McLaren's notion of critical literacy with special attention to social practices. By problematizing the texts read in class, students can embark on a path of social consciousness that examines texts beyond surface impressions, traditional myths, and clichés. For Comber (1993), the objectives of reading media texts as social practice focus on (1) helping students reposition themselves as researchers of language; (2) pushing students to understand and respect their resistance to mainstream interpretations of text and exploring minority culture constructions of literacy and language use; and (3) problematizing classroom and public texts. By linking texts to their life experiences, the students provide evidence of this being put into practice in the teaching/learning experiences addressed in the paper. For Isabel Braadbaart, "critical literacy can be used as a tool for understanding and improving the world" (GTC, n.d). As Vasquez (2017) suggests, "reading of any text is mediated through our day-to-day experience and the places, spaces, and languages that we encounter, use, and occupy". Critical reading should help students to unpack "myths and distortions and building new ways of knowing and acting upon the world" (Luke, 2014, p. 22). According to Janks (2014), "Different times and different places have their own inequities and iniquities that merit critical interrogation and intervention because interpretations reflect social inequities".

There is growing global interest in critical interest as shown in the work of Janks (2019) in South Africa, Comber $(2015 ; 2016)$ in Australia and Vasquez (2017) in Canada. Seminal works of these scholars have significantly shaped current understanding of 'doing' critical literacy. Though there is rising classroom-based research to support learners' development of criticality, not much has been done about teaching critical literacy in South African classrooms. Few classroom-based studies have 
been conducted, with most available classroom research focusing on school literacy practices and what occurs outside the classroom (Lloyd, 2016; McKinney, 2011; Makoe, 2014; Janks, 2014). Notably, Janks (2014) has argued that teachers should connect the text they bring to class to students' daily lives.

This paper reports on how secondary school students begin to develop critical literacy as part of a larger teaching critical literacy awareness project. The critical reading intervention strategy was implemented to Grade 12 English second language students, at a township school in South Africa. The project aimed to add to pedagogical developments in teaching critical literacy and language skills. Though critical literacy is recommended in the South African school curriculum, there is ambiguity on its implementation. Lack of official direction for South African language teachers is problematic because it limits potential for critical literacy teaching. Therefore, students miss on acquiring critical literacy skills. By choosing the newspapers as pedagogical tool, the study aimed to uncover how students view the world and understand how newspapers "link to the real-life" (Braadbaart, 2017).

The expected conclusion of this study is demonstrate that students can potentially develop to active readers in the ESL classroom. From a critical literacy perspective, (Freire, 1972) students are invited to read beyond the texts. Thus, on their reading and writing students should reflect various viewpoints and possibilities as they scrutinise "texts and their discourse structures as principle means for representing and reshaping possible worlds" (Luke, 2014, p. 10).

\subsection{Theoretical frameworks}

Different frameworks are suggested to create critical literacy awareness. Luke and Freebody (1999) suggest a 'four resources model' for classroom practice. One of Luke and Freebody's suggested roles for the reader is that of 'text analyst' that they describe as central to critical literacy development. This critical view recognises how "cultural dimensions of meaning are ascribed to texts and their production" (Kalir \& Garcia, 2019).

In addition, this study uses Fairclough's $(2013,2014)$ Critical Discourse Analysis (CDA). In this approach to text analysis, Fairclough (2013) offers one of the most influential frameworks for studying media language that interrogates language and power relations in texts, which is useful in teaching critical reading to language learners. CDA critiques assumptions about power and how language can provide a deeper understanding of power relations in society (Bogum, 2017). One main subject of investigation in CDA is the presence of ideology in texts, which emanates from Critical Linguistics. When interrogating language we analyze the imbalanced powers found in texts (Roberge, 2013). Several scholars view power as central tenet of critical literacy (Freire, 1972; Gee, 2015; Morrell, 2017). For Luke (2012, p. 5), critical literacy is "concerned with teaching learners to understand and manage the relationship between language and power by focusing on how texts work and in whose interests". Critical literacy is inherently political because of its main concern with language and power (Farrar \& Stone, 2019). Notably, Janks' (2014) framing of critical literacy integrates language and power.

\subsection{Classroom applications of critical literacy}

Luke (2014) views critical literacy as an "overtly political orientation to teaching and learning and to the cultural, ideological and sociolinguistic content of the curriculum" (p. 22). As Jordao and Fogaca (2012) note, critical literacy awareness should be more about understanding texts, rather than adapting readers to texts. This can develop students to active participants in the meaning-making process of reading texts, not simple passive replicators of norms. The benefit of critical literacy, as Jordao and Fogaca (2012) see it, is developing students' ability to see themselves, as well as seeing others, in a given text and thus gaining a deeper, more critical understanding of the way the world and how they are positioned in the world.

In this regard, research on critical reading is vital for advancing the field of Critical Literacy Awareness. Therefore, this study engages the concern that critical reading can equip students with critical literacy skills. Notably, the present study focuses on the use of different genres of texts to promote critical literacy awareness. Specifically, it attempts to answer the following questions: 
1. How does language position the readers and their construction of meaning?

2. How does the students' critical reading influence their understanding of the world and their position in the world?

\section{Method}

\subsection{Critical Discourse Analysis}

This article aims to demonstrate how Critical Discourse Analysis (CDA) can be applied as a conceptual framework for exploring teaching critical literacy using media discourse. However, this study is not predominantly aimed at demonstrating the application of CDA but presenting results of the research project focusing on critical reading of selected texts. It explores how conventional and unconventional texts can used as pedagogical tools in the English classroom. Here, the researcher explores mainly how newspapers can be used as pedagogical tools to teach students to be critical readers. The rationale is that newspapers are far reaching to different communities and, as a result, this accessibility and familiarity can have profound effect to students.

\subsection{Setting and Participants}

The study was carried out with English second language students at a secondary school in Topville Township ${ }^{1}$, a former Coloured ${ }^{2}$ residential area, west of Johannesburg. Townships are often underdeveloped segregated urban areas that were reserved for non-whites during the apartheid era (Huchzermeyer, 2011). Township schools are inherently poorly resourced. The 20 students in this study were aged between 17 and 19 years old. They were in Grade 12, which is a high school exit level in South Africa.

\subsection{Data Collection and Analysis Procedure}

Data were collected through class reading activities and students' reflections on them. In this learning and teaching project, the students did several class activities in pairs and groups. In these activities, the students were given the opportunity to think critically about language and question authors' intents as they read and analysed different texts including headlines, articles and a cartoon. The analysis process started with the researcher demonstrating how different newspaper headlines reflect different points of view and bias. After modelling the process, the students analysed newspaper headlines in pairs and constructed their own headlines, which they shared with the class. Second, in groups of four, the students read articles from different local newspapers and identified salient discourses in them, which they reported to the whole class. This was followed by critical response to the same articles as the students wrote 'letters to the editor'. Last, the students analysed a political cartoon.

\section{Findings and Discussion}

\subsection{Newspaper headlines and bias}

When introducing critical literacy awareness, I aimed to teach my students to read beyond mere words in a text. To achieve this aim, I presented them with newspaper headlines from different South African newspapers. Headlines are a valuable source for teaching because their distinctive syntactic properties determine a newspapers' grammatical peculiarity (Tabbert, 2015). Of particular interest are their lexical choices (Tabe \& Fieze, 2018) and "definable set of linguistic features" (Bednarek \& Caple, 2012, pp. 100-104). Apart from being studied for their clipped forms and conventional puns (Molek-Kozakowska, 2014), headlines have been noted for their potential to construct newsworthiness (Bednarek \& Caple 2012).

To answer the question, How does language position the reader and their construction of meaning?, the students read headlines from different local newspapers such as 'Daily Sun', 'Mail \& Guardian', 'Sowetan', 'Sunday Times' and 'The Star'. The main aim of the activity was for students

\footnotetext{
${ }^{1}$ Not real name

${ }^{2}$ Mixed race
} 
to identify linguistic features such as ellipsis, metaphor, pun and establish tone and point of view, including fact and opinion. First, the students inferred meanings of headlines when some words were added or omitted. Second, they analysed metaphor as a linguistic device used to compress meaning in headlines (Molek-Kozakowska, 2014). Despite metaphor being a linguistic feature, the students highlighted its potential to manipulate facts as one group noted: "The word 'Crucifiction' in the headline pertaining to Mr Zuma, creates an impression of innocence, meant to win him public sympathy". Further, the students conceived the South African press as highly polarised around ethnicity. They revealed that The Citizen mainly reported on cricket and rugby, which are popular among the South African white population, whereas Sowetan mainly reported on soccer, which is popular among the Black population who make up the majority of its readership. The students noted that newspapers such as 'Mail \& Guardian', with a predominant white readership, mainly used complex language as compared to Sowetan. This demonstrates how different newspapers use different lexes, forms and grammatical structures when reporting an event (Abbas \& Talaat, 2019). Important studies by Huang (2011) and Kumagai and Iwasaki (2011) concluded that when students analysed choice of words and themes in texts, they developed critical responses by questioning worldviews and power relations implied therein.

At the time this study was conducted, the most prominent news particularly related to rape allegations, which were made against Mr Jacob Zuma, the deputy president of South Africa at that time. Mr Jacob Zuma was accused of raping a 31-year-old family friend who was HIV positive. However, he was later acquitted of the charge in a highly publicised controversial decision. The case dominated headlines of leading local and international newspapers. The students found the news on the Zuma case most captivating because it was timeless. According to Bell (1991), "the best news is something which has only just happened" (p. 156). The following selected sample of headlines in Table 1 from different newspapers elicited interesting comments from students:

Table 1. Sample of newspaper headlines relating to Zuma case

\section{Newspaper headlines relating to Zuma case}

1. Zuma walks free from rape, corruption charges, Sowetan, 22 December 2006

2. Protesters clash at Zuma trial. Sowetan, 14 February, 2006

3. Apologise to Zuma. Sunday Times, 19 February, 2006

4. Zuma supporters fan fires of ethnicity and disrespect. Sowetan, 24 February 2006

5. Supporters bay for blood. Sowetan, 8 March 2006

6. $100 \%$ Zuluboy. Mail \& Guardian, 7-12 April 2006

7. I'm like Christ - Zuma. Sowetan, 24 March 2006

From the above headlines, the students identified emotive words such as 'walks free', 'clash', and 'fires'. When commenting on the simile, 'I'm like Christ', they dismissed it as 'Zuma being carried away with cheap popularity'. On the headline 'Zuma walks free from rape, corruption charges' the students observed "It creates an impression that the case was just nothing. Typical of our politicians. They can get away with anything". When analysing the headline, 'Zuma supporters bay for blood', they noted, "The metaphor creates an image of blood-thirsty supporters who can kill for their leader". After analysing the newspaper headlines, the students constructed 'their own' headlines expressing pro and anti-Zuma sentiments as illustrated in Table2.

Table 2. Students' newspaper headlines relating to Zuma case

\begin{tabular}{lll}
\hline \multicolumn{1}{c}{ Anti-Zuma } & Students' headlines \\
\cline { 2 - 3 } 1. Zuma to blame & \multicolumn{2}{c}{ Pro-Zuma } \\
2. Zuma justly accused & 8. Zuma blamed again \\
3. Zuma to face the music & 9 . Zuma falsely accused \\
4. It never pours but rains for Zuma & 10. Zuma sings his way to court \\
5. Zuma knocking at the jail's door & 11. All will pass for Zuma \\
6. The rise and fall of Zuma & 12. Zuma will never see the jail's door \\
7. Zuma is a fallen zero & 13. Zuma rises from the ashes \\
\hline
\end{tabular}


The selected sample of headlines shows students' attempt at criticality and demonstrate how different points of view can create bias. Most of the headlines were metaphorical idioms and clichés with pun. For example, they described the headline Zuma knocking at the jail's door as pun to Randy Crawford's version of the song, Knocking on the heaven's door. The different lexical choices in the students' headlines portray different points of view.

\subsection{Newspaper articles}

After working with newspaper headlines, I assumed that my students were ready to deal with longer texts - newspaper articles. This was an attempt at answering the question, How does the students' critical reading influence their understanding of the world and their position in the world? The newspaper articles were meant to expose the students to more media language. According to Bell (1991), media language can be studied sociolinguistically, in ways that illuminate the sociocultural analysis of news. Although Bell's work is typical 'variationist' sociolinguistics, it illustrates connections between linguistic features and capricious aspects of social context. The main contribution of this perspective is about news discourse (Bednarek \& Caple, 2012). Some researchers conceive news discourse in purely linguistic terms, focusing upon semiotic codes and conventions which other analysts consider as multimodal or "multisemiotic" (Drid, 2019). As Drid (2019) observes, inclusion of semiotic system of images contributes to the construction of reality as additional cardinal constituents.

In groups of four, the students analysed news articles from the local press. They chose articles, which, in news industry context, have news values (Bell, 1991; Bednarek \& Caple, 2012, 2014; Potts, Bednarek \& Caple, 2015). The students engaged with word choice, commonly termed 'political correct' language as one group noted: "At times journalist use language that does not hurt our feelings. For us who live in shacks, they call them 'informal settlements"".

To broaden their criticality, the students chose different newspaper articles relating to the Zuma case in order to establish different points of view. They identified pro and anti-Zuma sentiments conveyed in the articles. Because some of the articles were written before the case went to trial, the students speculated the outcome of the case. Those written after Mr Zuma was acquitted of the rape charges provided impetus for students to debate the merits and demerits of the case. In an open class discussion, the students made very interesting comments. I found the following comments very interesting:

\section{Extract 1: Comments on Jacob Zuma articles}

Mandy: I think that Zuma is not a good example to us youngsters. He must be punished for his crime. He betrayed the trust of a poor woman who is HIV positive.

Nono: I think there is more to this case than just rape. The writer of the article I read seems to think that Zuma is guilty because she hates him. Let's wait for the court outcome

The students' different points of view demonstrate some critical thinking. For example, when expressing strong conviction that Mr Zuma is guilty, Mandy uses the modal verb 'must', which acts as an imperative in her utterance. Janks (2010) provides examples of how choice of modal can help students express themselves imperatively or tentatively. However, Nono is critical of an article that she believes was biased against Mr Zuma. The students' contrasting views illustrate different reading positions (Janks, 2010). They develop to "autonomous thinkers who can engage in a constructive scepticism" (Daniel \& Auriac 2011, p. 420). The researcher's aim in article reading activity was to teach students to read 'with' or 'against' texts (Janks, 2010). As Janks (2019) advises, to read with the text, is more than decoding a text but requires the reader to understand the rhetorical context, which includes knowing when, where, why, and to whom the utterance was addressed.

After reading and analysing newspaper articles, the students developed their own texts. They wrote letters to the editor in response to particular articles they read. Some researchers have underlined the importance of not only analysing texts but also designing and producing them (Luke, 2013; Janks, 2010) as well as understand the position(s) from which we design and produce them (Janks, 2010; Vasquez, 2017). Janks (2010) highlights the need for students to "produce texts that matter to them in different formats and for different audiences and purposes [and] allow them to draw on and extend their range of semiotic resources" (p. 156). 


\subsection{The political cartoon}

Studies on media discourse have emphasized the importance of the political cartoon to express points of view or ideas (Marín-Arrese, 2019; Mondry, 2017; Hasanah, \& Hidayat, 2020). A). Cartoons often have exaggerated, entertaining and informative content (Hasanah, \& Hidayat, 2020). The cartoon provides a link between image and text, what Fairclough (2014) terms 'intertextual analysis' of news discourse within the paradigm of CDA. According to Hammett (2018), political cartoons provide literary spaces in which negotiations of power and resistance are expressed. Research has shown that using a cartoon in the classroom can have significant impact on critical thinking and student learning (Yin \& Fitzgerald, 2017). In Doing critical literacy, Janks (2014) presents classroom strategies to demonstrate how images can re/produce ideologies/discourses. Her model of critical literacy creates space for readers to start to question things that they took for granted and notice things they used to ignore.

For textual and semiotic analysis of images, the students chose the Jacob Zuma cartoon (Figure 1) because of the controversial 'reading' they anticipated it would invite. The controversial Zuma cartoon appeared in a Johannesburg newspaper, The Star, on 9 May 2006, after Mr Jacob Zuma was acquitted of the rape charges. Mr Zuma maintained his innocence throughout the trial and it was reported that he was suing leading newspapers and radio stations for 63 million rands (approx. US\$4m), claiming that their coverage and satirising of his trial was defamatory and biased (The Guardian, 2006). During the Zuma trial, a lot was speculated about the outcome of the case. Many people felt that Mr Zuma should have been found guilty. On the contrary, his supporters alleged that he was falsely accused. Some students like Lebo, viewed Zapiro, the cartoonist, as prejudiced against Zuma, "I don't like the tone in Zapiro's cartoon. It shows disrespect for the president". A caption on a photo in one newspaper read, "Crucifiction: Zuma insists that the media and his detractors want to nail him to the cross" (Sowetan 24 March 2006). Commenting on the caption the students equated it to propagandistic journalism (Benkler, Faris, \& Roberts, 2018) meant to sensationalise the case, which Hasanah and Hidayat (2020) consider as just portraying the view of cartoonists about a specific topic or current issues. The students made interesting comments regarding the showerhead on the cartoon, which depicted what was reported Zuma said in his defence for having unprotected sex. They quizzed, "We think Mr Zuma is out of touch with reality. How can he think that taking a shower after having unprotected sex can prevent him from getting HIV?" The showerhead was conceived a lexicon of humour, as one student suggested, "Zapiro's showerhead will haunt him for life". As students' comments demonstrate, although the alleged rape was Mr Zuma's private life, it was inextricably linked to his public life, which was a concern to South Africans.

The cartoon (see Fig.1) seemed to fascinate the students because of their prior knowledge of the case that it satirised. As Mondry (2017) asserts "the power of the political cartoon lies not in the specific artist's intent or success at fostering change but in the degree to which, and how, the cartoonist taps the collective consciousness of readers" (p. 79). In this activity, the students examined how the semiotic aspect of the cartoon complimented or replaced the linguistic texts. They further demonstrated how satire in cartoon can be used as news commentary, exemplifying intertextuality (Nordquist, 2021), as texts 'rub up against one another' (Newfield, 2011). The ability to analyse satire demonstrated the students' ability to engage with widespread themes such as gender-based violence. In their textual and semiotic analysis of the cartoon they reflected how it profiled the account of events surrounding Mr. Zuma's case: 1) Zuma emerges victorious from the high court and brandishing two fingers as a sign of victory - is this victory? We think the judge set Zuma free because of fear that his imprisonment would cause a civil war. He is a powerful man with a lot of influence on his supporters who follow him blindly 2) Although Zuma believes that his image is credible, we question his credibility. In addition to his infidelity, how can he have unprotected sex at this day and age? 3) The gun signifies violence. The positioning of the gun is interesting - it is positioned in front of his private parts. It has a double meaning. The machine gun is part of Zuma's mantra song umshini wami ${ }^{3}$ ) The shower-head signifies what Zuma said about having a shower to prevent him contracting HIV after having unprotected sex. We think that taking a shower may also mean that he was trying to wash away his $\sin /$ crime. It is like Pilate in the bible 5) The cartoon depicts Zuma/ Zulu culture as a manifestation

\footnotetext{
${ }^{3}$ My gun
} 
of male chauvinism. This last point demonstrates the students attempt at locating the discourse of gender relations within distorted Zulu culture.

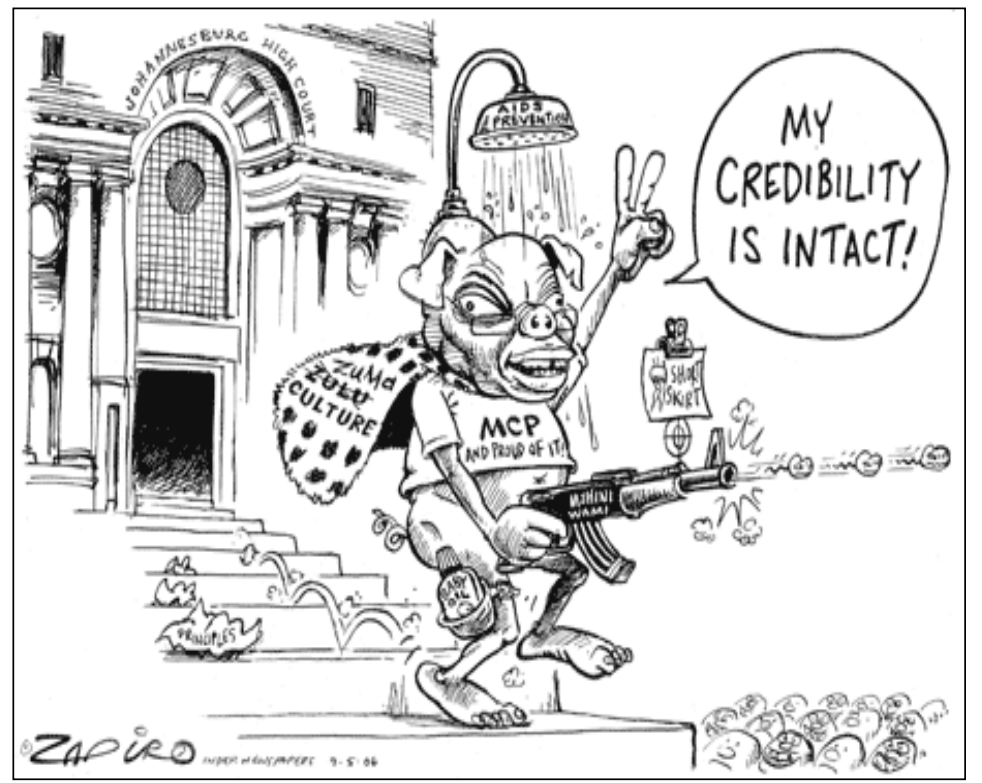

Fig. 1. Jacob Zuma cartoon. (Source: http://www.mg.co.za/ContentImage/2561/09-may06x.gif)

The class discussion shifted from the cartoon to the case itself as the students expressed great concern with finding Mr Zuma not guilty. They perceived the South African law as condoning the abuse of women. Important, they were highly critical of the reported conduct of Zuma's supporters (mostly women) who were demonstrating outside the Johannesburg High Court during the trial and chanting 'Burn the Bitch!' Meanwhile, inside the courtroom, Zuma's lawyers were 'grilling' Khwezi ${ }^{4}$, the woman who brought the case against Mr Zuma (Dempster, 2006). It was reported that Mr Zuma's lawyers questioned the accuser's sexual history - making public 'the prurient details for the whole world to hear' (Dempster, 2006). One student questioned the 'double standards' of the ruling African National Congress (ANC) Women's League, "The women's league is usually vocal on sexual abuse matters. Why did they treat another woman this way?" The class queried Mr Zuma's supporters for not questioning his moral indiscretion of infidelity and having unprotected sex. For the students, $\mathrm{Mr}$ Zuma's controversial life seemed to spill over to the scenes of his supporters outside the court. Thando, the most opinionated girl in the class, scorned, "I think those clowns who were dancing in the street in support of Zuma have blind faith like Boxer in 'Animal Farm'”. Reference to the docile character in George Orwell's allegory, reflects criticality of lack of reasoning. Another girl, Lusanda, presented a controversial divergent view, "With a rape case, no one will ever know the real truth except the two, the alleged rapist and the victim". This thought-provoking view may remind us of conception of witchcraft, in Arthur Miller's The Crucible, as ipso facto because the witch cannot accuse herself (sic) so the court relies on the victim.

An interesting view on gender-based violence emerged in a strong worded letter to the editor written by Thembi, one of the most outspoken students in the class:

What we read in the newspapers is an example of how men misuse their libido and power. They just let it run amok as they abuse powerless women. All these fat cats are the same. Look at how Goniwe harassed his 21-year-old secretary for refusing to sleep with him. And Bill Clinton too, how he took advantage of poor Monica.

For Thembi, 'fat cats', refers to rich people, particularly politicians, who amass wealth through dubious means. This reminds me of an interesting poster, which I saw at Botswana-South Africa

\footnotetext{
${ }^{4}$ Not her real name
} 
border post. The poster bore an image of handcuffs and a stark warning message, One size fits all, even the fat cats.

The 'Goniwe' case, involved Mbulelo Goniwe, a prominent member of the ANC, whom it was alleged wanted to sleep with his 21-year-old parliamentary intern. When the intern refused, he allegedly scorned her, "I thought you were a real Xhosa girl. How can you say 'no' to your chief whip as if I am an ordinary man?" (Commission on Gender Equality Report, 2006). The students condemned Goniwe's actions, as based on distorted Xhosa culture where a woman is not expected to refuse any man's sexual advances as Rose Moteme, a famous South African actor notes "Many men think it's fine to grope a woman's bum, lick someone's cleavage or make sexist jokes. And women are often too scared to stand up for themselves" (Sunday Times, 11 December 2005).

Similarly, one student in the class made a worrying remark, questioning the 'normalisation' of rape, "In our community rape is like a common culture. Many girls are violated and nothing happens to rapists. Boys don't take 'no' for an answer". Such comments demonstrate that sexual violence is a widespread sociocultural problem within South African communities. Mbuyiselwa Botha of 'South African Men's Forum against Violence' has uncovered two divergent views about the discourse of sexual violence: a worrying social issue and the belief that it is a Eurocentric idea with no place in African context where a man can decide how, when and where to have sex. According to Rachel Jewkes ${ }^{5}$, "rape is more common in countries with more pronounced gender hierarchy and in a culture where violence is used to exert dominance". As these views suggest, the abuse of women lies in a complex mix of factors, more to do with gender inequality and distorted cultural perceptions of what 'no' means. As Slovenian philosopher Slavoj Žižek, reminds us, "[the] point here is not that sometimes no doesn't mean no. It always means no" (Bulajewski, 2020) [emphasis not in original text].

The prominent cases of Sexual and gender-based violence (SGBV) cited by the students suggest awareness that the discourse of SGBV is much bigger than their township. Comparing the Goniwe case with the prominent Clinton-Lewinsky affair demonstrates familiarity with world affairs. In the Goniwe case, the 21-year-old intern was reported to have snubbed Goniwe's advances, whereas the then 22-year-old Lewinsky was alleged to have 'consented' to President Clinton's advances. However, controversy surrounds the perception that the Lewinsky affair was a case of two consenting adults as one boy in the class remarked, "How could Monica say no to the President, the most powerful man in America". In this regard, labelling Lewinsky a 'consenting adult', seems to underplay the disproportions between the president and an intern (Lewinsky, 2018). In Lewinsky's (2018) view, "given the power differential at play, it is not clear that such a relationship could ever be truly, fully consensual". For Lewinsky, her relationship with Clinton was "littered with inappropriate abuse of authority [and] privilege".

In 2018, a similar high profile sexual abuse case that dominated South African headlines and gender violence discourse involved Nigerian-born Pastor Omotoso and 23-year-old Cheryl Zondi. Cheryl described in harrowing detail how the 60 -year-old pastor allegedly sexually groomed and molested her several times, from the time she was 14 years old (Biyela, 2019). What emerged from the case was the lack of sensitivity by the courts towards gender-based violence victims. The adversarial tactic used by defense lawyers, which was witnessed at the Zuma trial, resurfaced at the Cheryl Zondi case. In an attempt to discredit Cheryl's credibility, the defense lawyers asked her how 'deep' Omotoso penetrated her, a tactic not only meant to humiliate and scare her but likely to make her relive the traumatic experience of the alleged molestation. The rudimentary treatment of sexual abuse victims in South African courts and low conviction rate of perpetrators is likely to send messages of hopelessness to several women. For many South Africans, particularly women and children who are victims of sexual violence, the message is clear "silence might be a better option" (Dempster, 2006). In South Africa, the extent of SGBV is not exactly known because only a few incidents are reported to authorities (Jewkes \& Dartnall, 2017). Results of a 2017 survey conducted in Gauteng showed that only about 1 in 23 women who were sexually abused reported the cases to the police (RSA 2020).

After undertaking the critical reading activity, Menzi wrote a letter to the editor, which partly read, 'All these stories tell of the sick and miserable life we face in the townships. It's scary, these killings,

${ }^{5}$ The Institute of War and Peace 6 May, 2006 report 
rapes, theft [...] they are like daily bread". Menzi's views are epitomic to crime prone South African townships. In addition, the students were empathic to the plight of Khwezi, the woman who brought the case against Mr Zuma. One girl, Nosizwe, wrote, 'People in high office abuse women and get away with it'. Another student, Giddy was more emotive, "When doing these activities, I was able to identify the sad mood and tone in the emotive language the reporters use. I real feel that I am a helpless victim of crime. It's sad and it makes me cry".

Findings of this study mirror the students' everyday experiences. Reference to prominent SGBV cases do not necessarily mirror previous studies but demonstrate the students' ability to articulate their thoughts and feelings in critical engagement with social events resonating with their personal experiences. The students demonstrate awareness of how deep-seated is the problem of sexual abuse, globally, and attempt to locate the discourse of sexual abuse within township culture.

\section{Conclusion}

In this study, the researcher hoped to encourage critical reading of newspapers and other texts in and outside the classroom. Although the students seemed to deviate from the primary aim of the critical reading project, lessons can be drawn on their critical discussion of social problems they encounter in their lives. As pedagogical tools, newspapers express controversial issues that students can examine from different perspectives. The activities carried out by the students proved productive in introducing them to critical reading. Every experience the students gained in each activity influenced their performance in the next one. The activities helped them understand the broader narrative of news. It can be concluded that the activities encouraged criticality because they related very closely to the students' experiences and scope of understanding. The students were even able to analyse the cartoon, a highly abbreviated literary genre. Drawing on Fairclough's (2014) concept of dialectical relationship between discourse and society, the students' responses reveal that their critical literacy was developed. They were able to challenge deep-rooted discourses of male chauvinism and cultural misrepresentation.

It is recommended that effective teaching should create an inclusive critical curriculum. Central to this curriculum is teaching what students may find relevant to their life experiences. As such, topics, issues and questions they may raise should spark interest in learning and further research.

\section{Declaration}

Author contribution : The author was in charge of conceptualization, data collection, data transcription.

Funding statement $\quad$ : The research is funded under no research project.

Conflict of interest $\quad$ : The author declares no conflict of interest.

Additional information: No additional information is available for this paper.

\section{REFERENCES}

Abbas, M. A., \& Talaat, M. (2019). Transitivity analysis of newspapers' news-headlines depicting crime committed against women in Pakistan. International Journal of English Linguistics, 9(5), 400-414. https://doi.org/10.5539/ijel.v9n5p400

Ahinkorah, B. O., Ameyaw, E. K., Hagan, J. E. Jr., Seidu, A. A., \& Schack, T. (2020). Rising above misinformation or fake news in Africa: Another strategy to control COVID-19 spread. Frontiers in Communication, 5, 45. https://doi.org/10.3389/fcomm.2020.00045

Allcott, H., \& Gentzkow, M. (2017). Social media and fake news in the 2016 election. Journal of Economic Perspectives, 3(2), 211-236. https://doi.org/10.1257/jep.31.2.211

Bednarek, M., \& Caple, H. (2017). The discourse of news values: How news organizations create newsworthiness. New York: Oxford University Press.

Bednarek, M., \& Caple, H. (2014). Why do news values matter? Towards a new methodological framework for analyzing news discourse in critical discourse analysis and beyond. Discourse \& Society, 20(10), 124. https://doi.org/10.1177/0957926513516041 
Bednarek, M., \& Caple, H. (2012). News Discourse. London/New York: Bloomsbury.

Bell, A. (1991). The language of news media. Oxford: Blackwell.

Benkler, Y., Faris, R., \& Roberts, H. (2018). Network propaganda: Manipulation, disinformation, and radicalization in American politics. New York: Oxford University Press.

Biyela, K. (2019). Cheryl Zondi in testimony shock https://www.pressreader.com/south-africa/you-southafrica/20190404/281539407308054

Bogum, Y. (2017). Critical literacies global and multicultural perspectives. Springer.

Braadbaart, I. (2017). It's not what you read, it's how you read it: Approaching critical literacy as a novice teacher http://readingchanges.blogspot.com/2017/11/its-not-what-you-read-its-how-you-read.html

Bulajewski, M. (2020). Getting a grip on Slavoj Žižek (with Slavoj Žižek) https://daily.jstor.org/ getting-agrip-on-slavoj-zizek-with-slavoj-zizek/

Comber, B. (2016). Literacy, place, and pedagogies of possibility. New York, NY: Routledge.

Comber, B. (2015) Critical literacy and social justice. Journal of Adolescent and Adult Literacy, 58(5), 362367. https://doi.org/10.1002/jaal.370

Comber B. 1993. Classroom explorations in literacy. Australian Journal of Language and Literacy 16(1), $73-$ 84.

Daniel, M. F., \& Auriac, E. (2011). Philosophy, critical thinking and philosophy for children. Educational Philosophy and Theory, 43, 415-435. https://doi.org/10.1111/j.1469-5812.2008.00483.x

Dempster, C. (2006). South African Trial brings rape into public view: High rates of sexual violence appear rooted in ingrained male attitudes. https://iwpr.net/global-voices/south-african-trial-brings-rape-publicview

Drid, T. (2019). The study of news: a discourse analysis perspective. Journal El-Bahith in Human and Social Sciences, 10(35), 701-708. https://doi.org/10.35156/1869-000-035-062

Farrar, J., \& Stone, K. (2019). Silenced by the gaps? The status of critical literacy in Scotland's curriculum for excellence. English Teaching: Practice and Critique. https://doi.org/10.1108/ETPC-03-2019-0041

Fairclough, N. (2014) Language and Power (Third Edition). London: Longman.

Fairclough, N. (2013). Critical discourse analysis: The critical study of language (Second Edition). London: Routledge.

Freire, P. (1972). Pedagogy of the oppressed. Harmondsworth, UK: Penguin.

Gainer, J. (2012). Critical thinking: Foundational for digital literacies and democracy. Journal of Adolescent \& Adult Literacy, 56(1), 14-17. https://doi.org/10.1002/JAAL.00096

Gee, J. P. (2015). The New Literacy Studies. In J. Rowsell \& K. Pahl (Eds.), The Routledge handbook of literacy studies (pp. 35-48), London: Routledge.

Hammett, D. (2018). Cartoonists can be an important voice of dissent: But they can also be divisive https://theconversation.com/cartoonists-can-be-an-important-voice-of-dissent-but-they-can-also-bedivisive- 104778

Hasanah, N., \& Hidayat, D. N. (2020). A semiotic analysis of political cartoons on the first 100 days of Anies Baswedan government. EduLite: Journal of English Education, Literature, and Culture, 5(2), 322-333. http://dx.doi.org/10.30659/e.5.2.322-333

Huang, S. Y. (2011). "Critical literacy helps wipe away the dirt on our glasses": Towards an understanding of reading as ideological practice. English Teaching: Practice \& Critique, 10(1), 140-164.

Huchzermeyer, M. (2011). Cities with 'slums': From informal settlement eradication to a right to the city in Africa. Cape Town: University of Cape Town Press.

Hughes, J. (2014). Critical thinking in the language classroom. Retrieved from https://www.ettoi.pl/PDF_resources/Critical_ThinkingENG.pdf. 
Janks, H. (2019). Critical Literacy and the importance of reading with and against a text. Journal of Adolescent \& Adult Literacy, 62(5), 561-564. https://doi.org/10.1002/jaal.941

Janks, H. (2014). Critical literacy's ongoing importance for education. Journal of Adolescent \& Adult Education, 57(5), 349-356. https://doi.org/10.1002/jaal.260

Janks, H. (2010). Literacy and power. New York, NY: Routledge.

Jewkes, R., Darnell, E. (2017). Sexual violence. In S. R., Quah, \& W. C., Cockerham, (Eds.), International encyclopedia of public health (pp. 491-498). Oxford, England: Elsevier.

Jordao, C. M., \& Fogaca, F. C. (2012). Critical literacy in the English language classroom. D.E.L.T.A., 28(1), 69-84.

Kalir, J. H., \& Garcia, A. (2019). Civic writing on digital walls. Journal of Literacy Research, 51(4), 42-443 https://doi.org/10.1177/1086296X1987720

Kress, G. (1985). Linguistic processes in sociocultural practice. Oxford: Oxford University Press.

Kumagai, Y., \& Iwasaki, N. (2011). What it means to read "critically" in a Japanese language classroom: Students' perspectives. Critical Inquiry in Language Studies, 8(2), 125-152.

Lankshear, C., \& McLaren, P. (1993). Critical literacy and the postmodern turn. In C. Lankshear, \& C. McLaren (Eds.). Critical literacy: Politics, praxis, and the postmodern (pp. 379-420). Albany, NY: State University of New York Press.

Lewinsky, M. (2018). Emerging from "the House of Gaslight" in the age of \#MeToo https://www.vanityfair.com/news/2018/02/monica-lewinsky-in-the-age-of-metoo

Lloyd, G. (2016). Are we teaching critical literacy? Reading practices in a township classroom. Reading \& Writing, 7(1), a97. http://dx.doi.org/10.4102/rw.v7i1.97

Luke, A. (2014). Defining critical literacy. In J. Z. Pandya \& J. Ávila (Eds.). Moving critical literacies forward: A new look at praxis across contexts (pp. 19-31). New York, NY: Routledge.

Luke, A. (2013). Regrounding critical literacy: Representation, facts and reality. In M. R. Hawkins (Ed.). Framing language and literacies: Socially situated views and perspectives (pp. 136-148). New York: Routledge.

Luke, A. (2012). Critical literacy: Foundational notes. Theory into Practice, 51, 4-11. https://doi.org/10.1080/00405841.2012.636324

Luke, A., \& Freebody, P. (1999). A map of possible practices: further notes on the four resources model. Practically Primary, 4(2), 5-8. https://search.informit.org/doi/10.3316/aeipt.96162

Makoe, P. (2014) Constructing identities in a linguistically diverse learning context, International Journal of Bilingual Education and Bilingualism, 17(6), 654-667. https://doi.org/10.1080/13670050.2014.953773

Marín-Arrese, J. I. (2019). Political cartoon discourse: Creativity, critique and persuasion. Culture, Language and Representation, 22,117-134. http://www.e-revistes.uji.es/index.php/clr/article/view/3958

McKinney, C. (2011). Asymmetrical relations of knowing: Pedagogy, discourse and identity in a de(re)segregated girls' school'. Journal of Education, 51, 1-2.

Mintarsih, S. S., Kodrat, D., \& Emiliasari, R. N. (2020). Tempo's perspective on the representation of government in dealing with covid-19 cases. Journal CALL, 2(2), 125-137.

Molek-Kozakowska, K. (2014). Coercive metaphors in news headlines: a cognitive-pragmatic approach. Brno Studies in English, 40(1), 149-173.

Mondry, H. (2017). A conversation on the politics of (Un-)natural substances: Ingesting psychoactive matter in 19th century Russian literature and culture. In Zeitschrift fur Slavische Philologie.

Morrell, E. (2017). Toward equity and diversity in literacy research, policy, and practice: A critical, global approach. Journal of Literacy Research, 49(3), 454-463. DOI: https://doi.org/10.1177/1086296X17720963

Newfield, D. (2011). From visual literacy to critical visual literacy: An analysis of educational materials. English Teaching: Practice and Critique, 10(1), 81-94. 
Nordquist, R. (2021). Intertextuality. Retrieved from https://www.thoughtco.com/what-is-intertextuality1691077

Ofcom (2016). Children and parents: Media use and attitudes report. Southwark, London: Ofcom. Retrieved from https:/www.ofcom.org.uk/_data/assets/pdf_file/0034/93976/Children-Parents-MediaUseAttitudes-Report-2016.pdf

Picton, I., \& Teravainen, A. (2017), Fake news and critical literacy: An evidence review. London: National Literacy Trust https://www.literacytrust.org.uk/account/login/?next=/documents/ 1278/Fake_news_and_critical_literacy_evidence_review_Sep_17.pdf

Potts, A., Bednarek, M., \& Caple, H. (2015). How can computer-based methods help researchers to investigate news values in large datasets? A corpus linguistic study of the construction of newsworthiness in the reporting on Hurricane Katrina. Discourse \& Communication, 9(2), 149-172. https://doi.org/10.1177/1750481314568548

Pratiwi, V. U., Nofrahadi, N., Pendri, A., Komalasari, D., \& Sumarlam, S. (2020). News text on Kompas.com media of Covid-19 and the underlying conspiracy theory: A Teun Van Dijk's critical discourse analysis. BIRCI-Journal: Budapest International Research and Critics Institute-Journal, 3(4), 3894-3903.

Roberge, G. D. (2013). Promoting critical literacy across the curriculum and fostering safer learning environments. What Works? Research into Practice, 48, 1-4.

RSA, (2020). National strategic plan on Gender Based Violence and Femicide (GBVF). Pretoria: Government Printers. https://www.justice.gov.za/vg/gbv/NSP-GBVF-FINAL-DOC-04-05.pdf

Shor, I., Matusov, E., Marjanovic-Shane, A., \& Cresswell, J. (2017). Dialogic \& critical pedagogies: An interview with Ira Shor. Dialogic Pedagogy: An International Online Journal, 5. https://doi.org/10.5195/dpj.2017.208

Stone, K. (2017). Reconsidering primary literacy: Enabling children to become critically literate. London: Routledge. https://doi.org/10.4324/9781315616674

Tabe, C. A. \& Fieze, N. I. (2018). A critical discourse analysis of newspaper headlines on the Anglophone crisis in Cameroon. British Journal of English Linguistics, 6(3), 64-83.

Tabbert, U. (2015). Crime and corpus: The linguistic representation of crime. Amsterdam: John Benjamins Publishing Company.

Tandoc, E., Lim, Z. W., Ling, R. (2017). Defining "Fake News": A typology of scholarly definitions. Digital Journalism, 6(3), 1-17. https://doi.org/10.1080/21670811.2017.1360143

The General Teaching Council for Scotland (GTC) (n.d). "I read it so it must be true" Retrieved from https://www.gtcs.org.uk/News/teaching-scotland/72-critical-literacy.aspx

Vasquez, V. M., Janks, H., \& Comber, B. (2019). Critical Literacy as a Way of Being and Doing. Language Arts, 96(5), 300-311. Retrieved from https://hilaryjanks.files.wordpress. com/2020 /09/vasquezjankscomber-cl_as_a_way_of_being_and-copy-3-1.pdf

Vasquez, V. M. (2017). Critical literacy http://education.oxfordre.com/view/10.1093/acrefore /9780190264093.001.0001/acrefore-9780190264093- e-20

Yin, Y. K., \& Fitzgerald, R. (2017). Peer learning with concept cartoons enhance critical thinking and performance in secondary school economics. Journal of Economic Education Research, 18(1), 1-13. 